\title{
Effect of Kyphoplasty in the Treatment of Osteoporotic Vertebral Fractures Compared to Vertebroplasty - Overview of Systematic Reviews
}

\section{Efeito da cifoplastia no tratamento de fraturas vertebrais osteoporóticas comparado ao da vertebroplastia - revisões das revisões sistemáticas publicadas}

\author{
Ricardo Vieira Botelho ${ }^{1} \quad$ Juliete Melo Diniz ${ }^{1} \quad$ Ulysses de Oliveira Sousa ${ }^{1}$ Marcelo Luís Mudo ${ }^{1}$ \\ Matheus Fernandes de Oliveira ${ }^{1}$ \\ 1 Post Graduation Program - Instituto de Assistência Médica ao \\ Servidor Público Estadual, São Paulo, SP, Brazil \\ Address for correspondence Ricardo Vieira Botelho, Rua Pedro de \\ Toledo, 1800, Vila Clementino, São Paulo, SP, Brazil, \\ Zip Code 04039-000 (e-mail: bitbot@uol.com.br).
}

Arq Bras Neurocir 2017;34:217-224.

\begin{abstract}
Keywords

- kyphoplasty

- vertebroplasty

- vertebral fracture

- osteoporosis
\end{abstract}

\section{Resumo}

Introduction Vertebroplasty and kyphoplasty are possible options for vertebral augmentation after osteoporotic fractures. Both are percutaneous techniques with specific advantages and disadvantages. Our aim is to compare the clinical and radiological results of these two procedures.

Methods An overview of published systematic reviews in the literature on the effects of kyphoplasty compared with vertebroplasty was performed.

Results After short and long follow-up, the kyphoplasty group had lower pain scores on the visual analogue scale (VAS), lower scores in the Oswestry Disability index (ODI), greater restoration of the vertebral body height and lower kyphosis angle in the immediate postoperative period. There was less leakage of cement to the vertebral canal and extraspinal spaces.

Conclusions Compared with vertebroplasty, kyphoplasty achieved better results in pain relief, quality of life, correction of spinal deformity and lower risk of cement leakage.

Introdução Vertebroplastia e cifoplastia são opções possíveis de tratamento para fraturas vertebrais osteoporóticas. Ambas são técnicas percutâneas com vantagens e desvantagens específicas. Nosso objetivo é comparar os resultados clínicos e radiológicos dos dois procedimentos.

Métodos Foi realizada uma revisão sistemática da literatura publicada sobre os efeitos da cifoplastia em comparação com a vertebroplastia.

Resultados No acompanhamento a curto e longo prazo, o grupo de cifoplastia teve valores mais baixos na escala visual analógica (EVA) de dor, valores mais baixos no received

August 8, 2017

accepted

September 19, 2017

published online

October 30, 2017
DOI https://doi.org/

10.1055/s-0037-1608000. ISSN 0103-5355.
Copyright $\odot 2017$ by Thieme Revinter

Publicações Ltda, Rio de Janeiro, Brazil
License terms

(c) (i) $\ominus$ (\$) 
Palavras-chave

- cifoplastia

- vertebroplastia

- fratura vertebral

- osteoporose índice de incapacidade de Oswestry (IIO), maior restauração da altura do corpo vertebral e menor ângulo de cifose no pós-operatório imediato. Houve menor incidência de extravasamento de cimento no canal vertebral e nos espaços extraespinhais.

Conclusões Em comparação com a vertebroplastia, a cifoplastia obteve melhores resultados no alívio da dor, na qualidade de vida, na correção de deformidade espinhal e menor risco de extravasamento de cimento.

\section{Introduction}

It is estimated that $30 \%$ of the people over the age of 65 will have a vertebral body compression fracture caused by osteoporosis. ${ }^{1}$ Osteoporotic fractures of the spine can lead to chronic pain, progressive deformity, reduced quality of life, and increased mortality. ${ }^{1-13}$

Since 1987, bone filling techniques have become progressively widespread, with benefits in the treatment of pain and associated deformity correction. ${ }^{5}$ Vertebroplasty was initially introduced as a spinal cementation method for treating pain and preventing or treating vertebral collapse. Its major drawback is that it involves the direct injection of cement at high temperatures into the Haversian canals within the trabecular bone, ${ }^{5}$ with risk of leakage into the spinal structures, potential damage to the spinal cord, and paraplegia. ${ }^{5,13-20}$

Kyphoplasty was developed to address the limitations and risks of vertebroplasty. The procedure was first performed in 1998, and its goals are similar to those of vertebroplasty. The technique, based on the principle of coronary stents, consists of placing an inflatable intravertebral balloon by the percutaneous route. The balloon creates a cavity which is then filled with cement in the same volume. Although there is an injection of cement at high temperature under pressure (similarly to vertebroplasty), it is not injected into the harversian canals but into a created cavity, lowering the risks of leakage. In addition, the intravertebral balloon can be expanded to restore the vertebral body height, which is not possible with the vertebroplasty. From a technical standpoint, kyphoplasty follows almost the same fluoroscopic principles used in vertebroplasty. ${ }^{21-30}$

The aim of this study is to evaluate the effect of kyphoplasty, compared with that of vertebroplasty, for the treatment of osteoporotic vertebral fractures, based on an overview of published reviews.

\section{Methods}

This study is a literature review of systematic reviews on the effects of kyphoplasty compared with vertebroplasty. References were retrieved electronically from the MEDLINE (via PubMed), Cochrane Database of Systematic Reviews and Google Scholar databases.

Only articles in English were considered. A structured search was conducted using the PICOT method, as described below:

Participants: Patients with osteoporotic vertebral fractures. Intervention: Kyphoplasty.
Controls: Vertebroplasty.

Outcomes: All clinically relevant outcomes.

Types of study: Published systematic reviews.

Search query: ("Kyphoplasty" [MeSH Terms] OR "kyphoplasty" [All Fields]) AND "Review" [Publication Type] - 272

\section{Methodological Quality Assessment}

We used the validated measurement tool to assess systematic reviews (AMSTAR) to evaluate the methodological quality of the retrieved studies. ${ }^{11-14}$ This tool consists of 11 questions designed to determine how strictly a systematic review was conducted. Each answer is assigned a score equivalent to one point per positive response. Quality is graded as low ( 0 to 4 points), moderate ( 5 to 8 points), or high (9 points or more)..$^{11-14}$

\section{Results}

Our search strategy yielded 31 records of systematic reviews, selected by title. Among these, the following reviews were analyzed: three reviews comparing kyphoplasty versus vertebroplasty versus conservative treatment; ${ }^{15-17}$ three reviews comparing kyphoplasty versus conservative treatment; ${ }^{18-20}$ and six reviews comparing kyphoplasty and vertebroplasty. ${ }^{17-19,21-23}$ Head-to-head comparisons of vertebroplasty versus kyphoplasty were the object of this analysis. Because there was an overlapping of the reviews above mentioned, the final number of studies evaluated was 9 ( - Fig. 1 and $\boldsymbol{\sim}$ Table $\mathbf{1}$ ).

\section{Data Extraction}

The latest review was published in $2016,^{6}$ and included 4 randomized trials, 14 prospective cohort studies, and 14 retrospective cohort studies for analysis. ${ }^{6}$

The second most recent review ${ }^{24}$ identified two randomized trials. The study conducted by Bae et $\mathrm{al}^{25}$ used Cortoss (Orthovita, Malvern, PA, USA) cement as the spinal fill method, and was thus excluded from our analysis, as all other studies used methyl methacrylate cements.

Wang et $\mathrm{al}^{26}$ identified only one randomized trial.

Taylor et al $(2007)^{19}$ evaluated five comparative studies, several non-comparative prospective studies, and no randomized trials.

Hulme et al (2006) ${ }^{22}$ also did not assess any randomized trial. Most of the analyzed studies were retrospective (37); 25 were prospective; and did not describe their designs. 


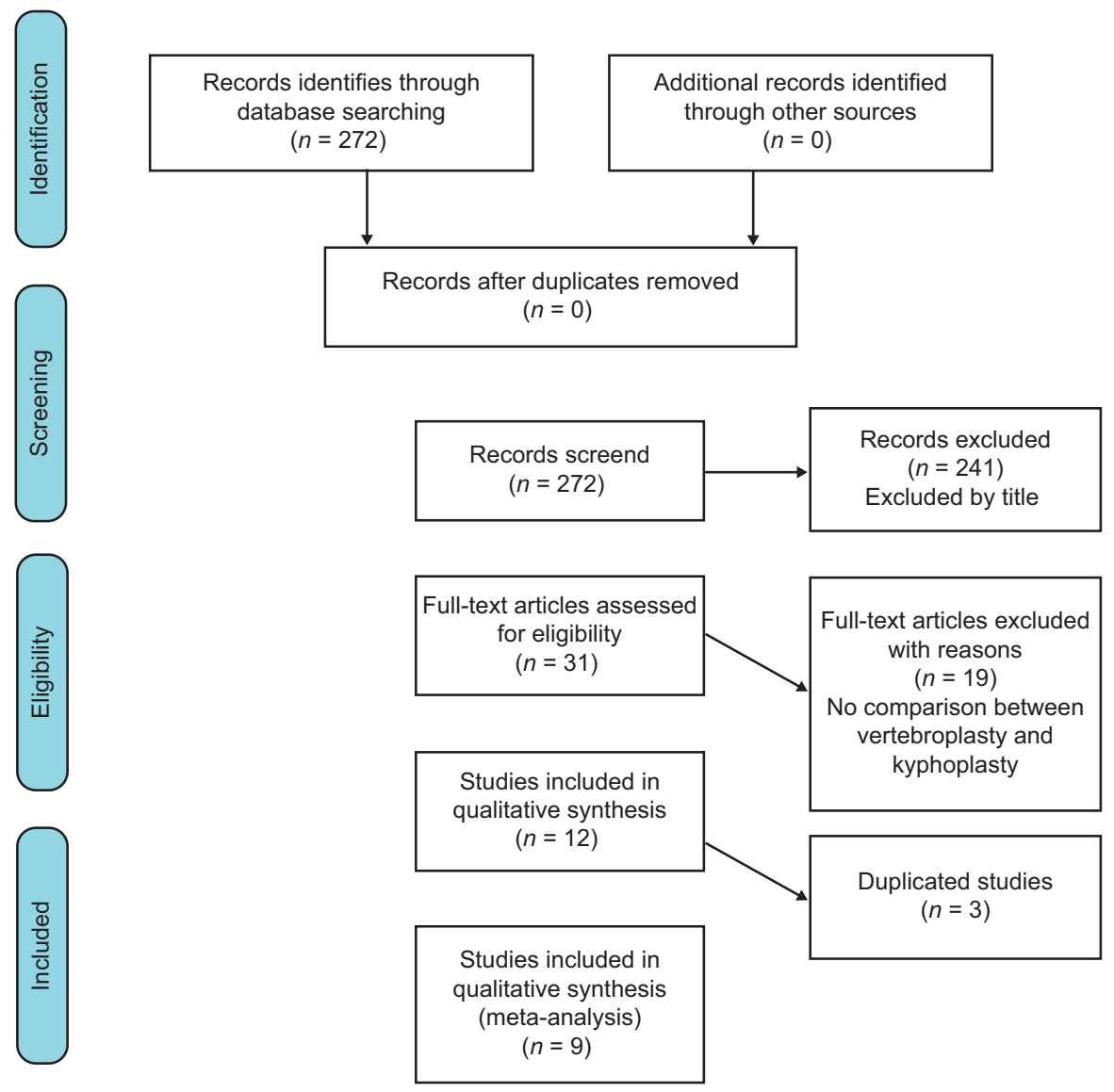

Fig. 1 Prisma flow diagram of evaluated studies.

Hsieh et al (2013) ${ }^{27}$ reviewed not only primary studies, but systematic reviews as well.

In 2014, a health technology assessment of percutaneous vertebroplasty and kyphoplasty was published by a UK group. $^{23}$ The authors identified nine randomized trials. Out of these, only one (Liu et al) directly compared kyphoplasty and vertebroplasty. ${ }^{28}$

The most complete and current review, which evaluated the largest number of publications, was conducted by Liang et al. $^{6}$ All the comparative studies, including 3,274 patients (1,653 undergoing kyphoplasty and 1,621 undergoing vertebroplasty), were covered in their meta-analysis. ${ }^{30-63}$

As stated by the current evidence regarding overviews of systematic reviews, it is possible to choose the last or the best existent review to be used as the main source for a final review. ${ }^{11-14}$ As the revision of Liang et al included all the described studies present in other revisions, this revision was selected for the data analysis, ensuring that there was no data duplication. Data are presented in -Table 1.

\section{Outcomes}

\section{Clinical}

Visual Analogue Scale (VAS)

Visual analogue scale at short-term follow-up (less than 1 week of follow-up): Eighteen studies reported results as weighted mean difference (WMD), with the kyphoplasty group scoring lower on the pain scale $(-0.2 ; 95 \% \mathrm{CI}-0.27$ to - $0.63 ; p<0.01)^{6,30-63}$

Visual analogue scale (after 6 months of follow-up): This outcome was assessed by 14 studies. Again, the kyphoplasty group had lower scores on the pain scale $(-0.46$; $95 \% \mathrm{CI}-0.57$ to - 0.36; $p<0.01)^{6,18-63}$

\section{Oswestry Disability Index (ODI)}

The short-term ODI scores were evaluated by 7 studies. The difference between the kyphoplasty and vertebroplasty groups was significant $(-17.56 ; 95 \% \mathrm{CI}-18.07$ to -17.05 ; $p<0.01)^{6,18-63}$

Regarding the clinical outcomes of both techniques, the pooled analysis revealed a statistically significant difference favoring kyphoplasty compared with vertebroplasty in the short-term and long-term VAS, ${ }^{6}$ yielding lower scores than vertebroplasty. The difference, however, was insufficient to achieve clinical benefit. The minimal clinically significant difference in short-term ODI scores varies in the literature, but 17 points favoring kyphoplasty has been considered as clinically significant.

\section{Radiological}

The height of the anterior third of the vertebral body was evaluated in 14 studies. On late follow-up, patients undergoing kyphoplasty had a higher standardized average difference in 
Table 1 Summarized data from reviews evaluated in the present manuscript

\begin{tabular}{|c|c|c|c|}
\hline Author/Year & Liang et al, 2016 & Bouza et al, 2006 & Taylor et al, 2007 \\
\hline Included studies & 32 (4 RCTs) & 26 & 43 \\
\hline Objective & $\begin{array}{l}\text { To compare clinical/radiological } \\
\text { outcomes and complication of KP/VP. }\end{array}$ & $\begin{array}{l}\text { To analyze the collected body of } \\
\text { evidence regarding the efficacy and } \\
\text { safety of KP in the treatment of VCFs. }\end{array}$ & $\begin{array}{l}\text { update of a previous systematic } \\
\text { review and meta-analysis of the } \\
\text { efficacy and safety of KP }\end{array}$ \\
\hline $\begin{array}{l}\text { Clinical } \\
\text { outcomes }\end{array}$ & $\begin{array}{l}\text { Short-term and Long-term VAS scores } \\
\text { were evaluated. The result showed a } \\
\text { significant difference favoring KP. }\end{array}$ & $\begin{array}{l}\text { Data from comparative studies: } \\
\text { Combined analysis of the studies shows } \\
\text { KP to yield a mean reduction in pain } \\
\text { intensity that is } 55.6 \% \text { greater than that } \\
\text { afforded by conservative management } \\
\text { The results of a retrospective analysis of } \\
\text { KP versus vertebroplasty in tumoral } \\
\text { VCFs show that, globally, no significant } \\
\text { differences are found between the two } \\
\text { techniques in terms of pain relief. }\end{array}$ & $\begin{array}{l}\text { Data from comparative studies: } \\
\text { VAS pain was significantly reduced } \\
\text { with KP at } 3,6,12 \text { and } 36 \text { months } \\
\text { follow up }(p<0.001) \text {. These reduc- } \\
\text { tions in pain were greater (than those } \\
\text { observed at the same point in time } \\
\text { with medical care treatment). }\end{array}$ \\
\hline $\begin{array}{l}\text { Radiological } \\
\text { outcomes }\end{array}$ & $\begin{array}{l}\text { Kyphoplasty resulted more improve- } \\
\text { ment in the kyphotic angle (immediate } \\
\text { and final follow-up) than with the VP } \\
\text { procedure }\end{array}$ & $\begin{array}{l}\text { Comparative studies: } \\
\text { KP } \times \text { VP: KP produces a statistically } \\
\text { significant improvement in local } \\
\text { kyphosis }\end{array}$ & $\begin{array}{l}\text { Two studies reported improvement in } \\
\text { the vertebral height and kyphotic } \\
\text { angle with KP at follow-up. These } \\
\text { improvements exceeded those of } \\
\text { vertebroplasty }\end{array}$ \\
\hline Complications & $\begin{array}{l}\text { No significant differences in the rate of } \\
\text { postoperative fractures. } \\
\text { Cement leakage to the intraspinal } \\
\text { space was more frequently observed in } \\
\text { the VP group }(p=0.35) \text {. }\end{array}$ & $\begin{array}{l}\text { Evaluation of the } 19 \text { studies that } \\
\text { contribute data shows a total of } 134 \\
\text { cement leakages in } 1,742 \text { treated } \\
\text { levels, out of which only } 1.5 \% \text { are } \\
\text { described as symptomatic or cause } \\
\text { clinical sequelae. } \\
\text { Combined analysis of two comparative } \\
\text { studies showed that patients subjected } \\
\text { to kyphoplasty are at a significantly } \\
\text { lesser risk of suffering new fractures } \\
6 \text { months after the procedure than } \\
\text { patients in the comparator group } \\
\text { studies subjected to medical } \\
\text { management. }\end{array}$ & $\begin{array}{l}\text { A total of } 189 \text { cement leakages were } \\
\text { reported in } 2,239 \text { vertebrae } \\
\text { submitted a KP. This corresponds to } \\
81 \text { cement leaks per } 1,000 \text { fractures } \\
\text { undergoing KP per year } \\
\text { KP: A total of } 171 \text { new or incident } \\
\text { fractures were reported in } 1,151 \\
\text { patients across } 16 \text { studies, } 110 \text { (64\%) } \\
\text { of which occurred in the vertebrae } \\
\text { adjacent to the procedure. }\end{array}$ \\
\hline Author/Year & Ma et al, 2012 & Papanastassiou et al, 2012 & Shi-Ming et al, 2015 \\
\hline Included studies & $12(1 \mathrm{RCT})$ & 27 & 11 \\
\hline Objective & $\begin{array}{l}\text { To evaluate the safety and efficacy of } \\
\text { (KP) compared with (VP) and provide } \\
\text { recommendations for using these } \\
\text { procedures to treat (VCF). }\end{array}$ & $\begin{array}{l}\text { To determine if differences in safety or } \\
\text { efficacy exist between KP, VP and } \\
\text { conservative treatment of osteoporotic } \\
\text { vertebral fractures }\end{array}$ & $\begin{array}{l}\text { To determine the efficacy and safety } \\
\text { for the treatment of VCFs to reach a } \\
\text { relatively conclusive answer }\end{array}$ \\
\hline $\begin{array}{l}\text { Clinical } \\
\text { outcomes }\end{array}$ & $\begin{array}{l}\text { Long-term VAS scores: the RCT and CCT } \\
\text { subgroup analyses found no significant } \\
\text { differences between the KP and VP } \\
\text { groups. However, the cohort study } \\
\text { subgroup analysis found that KP was } \\
\text { more effective than VP }\end{array}$ & $\begin{array}{l}\text { Pain reduction in both KP and VP was } \\
\text { superior to that observed in conserva- } \\
\text { tive treatment, while no difference was } \\
\text { found between KP and VP }(p=0.35)\end{array}$ & $\begin{array}{l}\text { VAS: The short-term subgroup found } \\
\text { that KP was more effective than VP, } \\
\text { but subgroup analysis of long-term } \\
\text { did not find a significant difference } \\
\text { between the VP and KP groups. }\end{array}$ \\
\hline $\begin{array}{l}\text { Radiological } \\
\text { outcomes }\end{array}$ & $\begin{array}{l}\text { Long-term postoperative kyphosis } \\
\text { angles. The RCT and cohort study } \\
\text { subgroup analyses found that the mean } \\
\text { long-term kyphosis angle of the KP } \\
\text { patients was significantly smaller than } \\
\text { the angle of the VP patients. However, } \\
\text { CCT subgroup analysis did not find a } \\
\text { significant difference between the KP } \\
\text { and VP patients. }\end{array}$ & $\begin{array}{l}\text { Kyphoplasty resulted in greater } \\
\text { kyphosis reduction than VP } \\
\left(4.88 \text { versus } 1.7^{\circ}, \mathrm{P} \mid 0.01\right)\end{array}$ & $\begin{array}{l}\text { Short-term kyphotic angle: the VP } \\
\text { and KP patients did not differ signifi- } \\
\text { cantly in the USA subgroup. However, } \\
\text { the Europe and Asia subgroups ana- } \\
\text { lysis found that KP was more effective } \\
\text { than VP }\end{array}$ \\
\hline Complications & $\begin{array}{l}\text { The overall pooled analysis of bone } \\
\text { cement leakage found a significantly } \\
\text { lower rate in KP patients than in VP } \\
\text { patients. However, the CCT subgroup } \\
\text { analysis did not find a significant } \\
\text { difference between the KP and VP } \\
\text { groups } \\
\text { Adjacent vertebral fracture: there were } \\
\text { no significant differences between the } \\
\text { KP and VP patients in any of the } \\
\text { subgroups analyzed }\end{array}$ & $\begin{array}{l}\text { Cement extravasation, reported as an } \\
\text { event rate, was significantly less } \\
\text { frequent for KP, than for VP. } \\
\text { Subsequent fractures occurred more } \\
\text { frequently in the conservative group } \\
\text { compared with VP and KP }\end{array}$ & $\begin{array}{l}\text { Cement leakage: the pooled analysis } \\
\text { showed that there was no significant } \\
\text { difference between these two } \\
\text { interventions. } \\
\text { Adjacent fractures: these two } \\
\text { interventions had similar risk for a } \\
\text { subsequent fracture }\end{array}$ \\
\hline
\end{tabular}


Table 1 (Continued)

\begin{tabular}{|c|c|c|c|}
\hline Author/Year & Liang et al, 2016 & Bouza et al, 2006 & Taylor et al, 2007 \\
\hline Author/Year & Robinson et al,2012 & Hulme et al, 2006 & Stevenson et al, 2014 \\
\hline Included studies & 8 & 69 & 9 RCTs \\
\hline Objective & $\begin{array}{l}\text { This systematic review analyses } \\
\text { randomized controlled trials on VP and } \\
\text { KP to provide an overview on the } \\
\text { current evidence }\end{array}$ & $\begin{array}{l}\text { To evaluate the safety and efficacy of } \\
\text { VP and KP }\end{array}$ & $\begin{array}{l}\text { To evaluate the clinical effectiveness } \\
\text { and cost-effectiveness of VP and KP in } \\
\text { reducing pain and disability in people } \\
\text { with VCFs in England and Wales. }\end{array}$ \\
\hline $\begin{array}{l}\text { Clinical } \\
\text { outcomes }\end{array}$ & $\begin{array}{l}\text { All treatment and control groups had } \\
\text { significant improvement from baseline } \\
\text { to follow-up at } 1,3 \text {, and } 12 \text { months } \\
\text { Pooled analyze not described }\end{array}$ & $\begin{array}{l}\text { Visual analog pain scores (VAS) were } \\
\text { reduced from an average of } 8.2 \text { and } \\
7.15 \text { to } 3.0 \text { and } 3.4 \text { for vertebroplasty } \\
\text { and kyphoplasty, respectively }\end{array}$ & - \\
\hline $\begin{array}{l}\text { Radiological } \\
\text { outcomes }\end{array}$ & Not evaluated & $\begin{array}{l}\text { Mean kyphotic angle restoration was } \\
6.6^{\circ} \text { and } 6.6^{\circ} \text { for vertebroplasty and } \\
\text { kyphoplasty, respectively. Not all } \\
\text { subjects had a reduction in kyphotic } \\
\text { angle or restoration of height ( } 34 \% \text { and } \\
39 \% \text { of KP and VP interventions) }\end{array}$ & $\begin{array}{l}\text { Four studies reported changes in } \mathrm{BH} \\
\text { and/or angular deformity. However, } \\
\text { because of because of heterogeneity, } \\
\text { the data was not pooled. }\end{array}$ \\
\hline Complications & Not evaluated & $\begin{array}{l}\text { Cement leakage occurred for } 41 \% \text { and } \\
9 \% \text { of treated vertebrae for vertebro- } \\
\text { plasty and kyphoplasty, respectively. } \\
\text { New fractures of adjacent vertebrae } \\
\text { occurred for both procedures at rates } \\
\text { that are approximately equivalent to } \\
\text { the general osteoporotic population } \\
\text { that had a previous vertebral fracture. }\end{array}$ & $\begin{array}{l}\text { Cement leakage: the pooled data } \\
\text { suggest an incidence of } 44 \% \text { for VP } \\
\text { compared with } 27 \% \text { for KP } \\
\text { Only three studies reported the } \\
\text { number of patients who suffered new } \\
\text { radiographic vertebral fractures } \\
\text { during the study period. None of } \\
\text { these studies found a statistically } \\
\text { significant difference between } \\
\text { treatment groups }\end{array}$ \\
\hline
\end{tabular}

Abbreviations: CCT, controlled clinical trial; KP, kyphoplasty; RCT, randomized controlled trial; VAS, visual analogue scale; VBH, vertebral bone height; VCF, vertebral compression fractures; VP, vertebroplasty.

the vertebral body height (greater correction) $(2.79 ; 95 \% \mathrm{CI}$ 2.39 to $3.19 ; p<0.01)^{6,18-63}$

The height of the middle third of the vertebral body was greater in the kyphoplasty group, as measured by the standardized mean difference $(6.92 ; 95 \%$ CI 6.31 to 7.52 ; $p<0.01)^{6,18-63}$

The kyphosis angle in the immediate postoperative period was evaluated in 15 studies, and showed greater improvement in the kyphoplasty group compared with the vertebroplasty group $(-2.5 ; 95 \% \mathrm{CI}-2.16$ to $-2.84 ; p<0.01)$. The kyphotic angle in the late postoperative period was assessed by 9 studies, and the kyphoplasty group was again superior to the vertebroplasty group. ${ }^{6,18-63}$ The clinical and radiological outcomes are briefly summarized in -Table 2.

\section{Complications}

Cement leakage into the vertebral canal was less frequent in the kyphoplasty group than in the vertebroplasty group (OR $0.5 ; 95 \%$ CI 0.3 to $0.85 ; p=0.035$ ). Extraspinal leakage was also less frequent with kyphoplasty than with vertebroplasty (OR 0.36 ; $95 \%$ CI 0.21 to $0.62 ; p=0.15$ ). ${ }^{6,18-63}$

Adjacent vertebral fractures were reported in 3 studies, with no significant difference between techniques. ${ }^{6,18-63}$

\section{Methodological Quality Assessment of Selected Reviews}

The sole review selected for analysis (Liang 2016) was assigned 7 of 11 possible points on the AMSTAR score, corresponding to a moderate methodological quality. ${ }^{11-14}$

Table 2 Clinical and radiological outcomes compared between kyphoplasty (KP) and vertebroplasty (VP)

\begin{tabular}{|l|l|l|l|l|}
\hline \multicolumn{2}{|l|}{ Outcome } & \multicolumn{2}{l|}{ Result } & \multicolumn{1}{l|}{ Statistics } \\
\hline \multirow{3}{*}{ Clinical } & VAS & Short term & Kp $<$ VP & $p<0.01$ \\
\cline { 2 - 5 } & & Long term & $\mathrm{Kp}<\mathrm{VP}$ & $p<0.01$ \\
\cline { 2 - 5 } & $\mathrm{ODI}$ & - & $\mathrm{Kp}<\mathrm{VP}$ & $p<0.01$ \\
\hline \multirow{3}{*}{ Radiological } & Height of anterior third of the vertebral body & - & $\mathrm{KP}>\mathrm{VP}$ & $p<0.01$ \\
\cline { 2 - 5 } & Height of middle third of the vertebral body & - & $\mathrm{KP}>\mathrm{VP}$ & $p<0.01$ \\
\cline { 2 - 5 } & Kyphosis angle & - & $\mathrm{KP}>\mathrm{VP}$ & $p<0.01$ \\
\hline
\end{tabular}

Abbreviations: KP, kyphoplasty; ODI, Oswestry Disability Index; VAS, visual analogue scale; VP, vertebroplasty.

In all analyzed outcomes, kyphoplasty was superior to vertebroplasty. There were lower scores in visual analogue scale (VAS) and Oswestry disability index (ODI), and better increase in the height of vertebral body and in the kyphosis angle. 


\section{Discussion}

Vertebral body fractures secondary to osteoporosis are highly prevalent and cause significant morbidity. They are associated with chronic pain, progressive deformity, reduced quality of life, and increased mortality. While treatment can be conservative or surgical, spinal augmentation techniques play a key role in the management of these cases, as they are effective and minimally invasive options. ${ }^{1-30}$

Vertebroplasty was the first vertebral augmentation technique to be implemented. Although technically effective, it has the drawback of requiring direct injection of cement at high temperature and pressure directly into the Haversian canal system within the trabecular bone, with a risk of leakage into the spinal and extraspinal structures. ${ }^{1-30}$ Of particular concern is the possibility of high-temperature cement leakage from the Haversian canals into the epidural veins. The vertebral venous content oscillates with the vertebral deformation during the endplate loading. This contributes to the communication into the vertebral venous plexus and, potentially, a cement leakage into the vertebral canal and spinal cord injury. Kyphoplasty has the advantage of using a balloon to create an intraosseous cavity that allows the injection of intracavitary bone cement with lower leakage risk. ${ }^{1-30}$

Although there are many studies on these two techniques, there is no consensus in the literature regarding the superiority of one method over the other. We conducted a systematic review of literature reviews to synthesize the current concept of their clinical efficacy. ${ }^{1-30}$

In our literature review, we identified three systematic reviews comparing kyphoplasty versus vertebroplasty versus conservative treatment, all limited to randomized studies. Only one randomized study comparing both techniques was described. ${ }^{28}$

Regarding the clinical outcomes of both techniques, kyphoplasty was superior to vertebroplasty in short-term and long-term VAS and short-term ODI, yielding lower scores than vertebroplasty. Pain control was more effective with kyphoplasty. ${ }^{6}$

Regarding radiological outcomes, kyphoplasty achieved greater differences in the height of the anterior third and middle third of the vertebrae, reflecting better reestablishment of the bone architecture. The kyphotic angles in the immediate and late postoperative period were also significantly lower in the kyphoplasty group compared with the vertebroplasty group, which is consistent with greater correction of the deformity. ${ }^{6}$

Osteoporotic deformities are another factor that contributes to pain, discomfort, and impaired quality of life. Promoting optimal correction of the deformity has direct implications for pain management and spinal sagittal imbalance correction. Kyphoplasty was superior to vertebroplasty in correcting deformities in the sagittal plane. ${ }^{6}$

Cement leakage and adjacent vertebral fractures were evaluated as complications. Leakage of cement into the vertebral canal and extraspinal spaces was significantly more frequent in the vertebroplasty than in the kyphoplasty group. Conversely, fractures in the adjacent vertebral levels were reported in few studies, without evidence of a significant difference between the techniques. ${ }^{6}$

Complications arising from vertebroplasty may be classified as mild (temporary increase in pain, transient hypotension), moderate (infection, leakage of cement into the foraminal, epidural, or dural space), or severe (cement leakage into the paravertebral veins, pulmonary embolism, cardiac perforation, cerebral embolism, or even death). Leakage of cement into the epidural or foraminal space is considered a rare complication. However, as most cases are clinically silent, the true prevalence may be as high as $40 \%$. Paraplegia due to a cement-related spinal cord compression may occur in $0.4 \%$ of patients. Needle traversal of laminae instead of the pedicle can occur, especially in the thoracic vertebrae, where the pedicle is smaller; this can lead to catastrophic complications. ${ }^{6}$

The optimal method should concentrate the deposition of bone cement into the vertebrae, preferably supporting the middle and anterior thirds of the spinal column, which are the main sites of bone loss. Furthermore, the ideal method would isolate the cement from the rich neurovascular structures in the vicinity. In this line, the vertebral canal and extravertebral cement leakage rates were lower with kyphoplasty than with vertebroplasty.

Therefore, the current evidence supports that kyphoplasty has superior efficacy in terms of clinical and radiographic outcomes and is associated with fewer complications than vertebroplasty.

This study is limited by the absence of a definitive guideline for conducting literature reviews of systematic reviews. Instead, we modeled our design after suggestions and published guidelines. Furthermore, we evaluated all the available reviews, but only the last one (Liang et al) was chosen as a parameter, as it was the most recent and robust, and it contained all the published studies of interest.

New randomized trials should be encouraged to analyze larger samples of patients and assess the heterogeneity of effects.

Conflicts of Interest

Authors declare no conflicts of interest

\section{References}

1 Bonnick SL. Osteoporosis in men and women. Clin Cornerstone 2006;8(01):28-39

2 Yeh ML, Heggeness MH, Chen HH, Jassawalla J, Luo ZP. Compressive loading at the end plate directly regulates flow and deformation of the basivertebral vein: an analytical study. J Orthop Surg 2006;1:18

3 Oleksik A, Ott SM, Vedi S, Bravenboer N, Compston J, Lips P. Bone structure in patients with low bone mineral density with or without vertebral fractures. J Bone Miner Res 2000;15(07):1368-1375

4 Lyles KW, Gold DT, Shipp KM, Pieper CF, Martinez S, Mulhausen PL. Association of osteoporotic vertebral compression fractures with impaired functional status. Am J Med 1993;94(06):595-601

5 Takata S, Yasui N. Disuse osteoporosis. J Med Invest 2001;48 (3-4):147-156

6 Liang L, Chen X, Jiang W, et al. Balloon kyphoplasty or percutaneous vertebroplasty for osteoporotic vertebral compression fracture? An updated systematic review and meta-analysis. Ann Saudi Med 2016;36(03):165-174 
7 Martelli N, Devaux C, van den Brink H, Pineau J, Prognon P, Borget I. A Systematic Review of the Level of Evidence in Economic Evaluations of Medical Devices: The Example of Vertebroplasty and Kyphoplasty. PLoS One 2015;10(12):e0144892

8 Martín-López JE, Pavón-Gómez MJ, Romero-Tabares A, MolinaLópez T. Stentoplasty effectiveness and safety for the treatment of osteoporotic vertebral fractures: a systematic review. Orthop Traumatol Surg Res 2015;101(05):627-632

9 Feng H, Huang P, Zhang X, Zheng G, Wang Y. Unilateral versus bilateral percutaneous kyphoplasty for osteoporotic vertebral compression fractures: A systematic review and meta-analysis of RCTs. J Orthop Res 2015;33(11):1713-1723

10 Guo JB, Zhu Y, Chen BL, et al. Surgical versus non-surgical treatment for vertebral compression fracture with osteopenia: a systematic review and meta-analysis. PLoS One 2015;10(05): e0127145

11 Whitlock EP, Lin JS, Chou R, Shekelle P, Robinson KA. Using existing systematic reviews in complex systematic reviews. Ann Intern Med 2008;148(10):776-782

12 White CM, Ip S, McPheeters M, et al. Using Existing Systematic Reviews to Replace De Novo Processes in Conducting Comparative Effectiveness Reviews. In: Agency for Healthcare Research and Quality. Methods Guide for Comparative Effectiveness Reviews. Rockville, MD: Agency for Healthcare Research and Quality; September 2009http://effectivehealthcare.ahrq.gov

13 Robinson KA, Whitlock EP, Oneil ME, et al. Integration of Existing Systematic Reviews. AHRQ Publication No. 14-EHC016-EF. Rockville, MDAgency for Healthcare Research and Quality.; June 23, 2014http://effectivehealthcare.ahrq.gov

14 Robinson KA, Whitlock EP, Oneil ME, et al. Integration of existing systematic reviews into new reviews: identification of guidance needs. Syst Rev 2014;3:60

15 Bouza C, López T, Magro A, Navalpotro L, Amate JM. Efficacy and safety of balloon kyphoplasty in the treatment of vertebral compression fractures: a systematic review. Eur Spine J 2006; 15(07):1050-1067

16 Taylor RS, Taylor RJ, Fritzell P. Balloon kyphoplasty and vertebroplasty for vertebral compression fractures: a comparative systematic review of efficacy and safety. Spine 2006;31(23): 2747-2755

17 Ma XL, Xing D, Ma JX, Xu WG, Wang J, Chen Y. Balloon kyphoplasty versus percutaneous vertebroplasty in treating osteoporotic vertebral compression fracture: grading the evidence through a systematic review and meta-analysis. Eur Spine J 2012;21(09): 1844-1859

18 Papanastassiou ID, Phillips FM, Van Meirhaeghe J, et al. Comparing effects of kyphoplasty, vertebroplasty, and non-surgical management in a systematic review of randomized and non-randomized controlled studies. Eur Spine J 2012;21(09):1826-1843

19 Taylor RS, Fritzell P, Taylor RJ. Balloon kyphoplasty in the management of vertebral compression fractures: an updated systematic review and meta-analysis. Eur Spine J 2007;16(08):1085-1100

20 Shi-Ming G, Wen-Juan L, Yun-Mei H, Yin-Sheng W, Mei-Ya H, YanPing L. Percutaneous vertebroplasty and percutaneous balloon kyphoplasty for osteoporotic vertebral compression fracture: A metaanalysis. Indian J Orthop 2015;49(04):377-387

21 Robinson Y, Olerud C. Vertebroplasty and kyphoplasty-a systematic review of cement augmentation techniques for osteoporotic vertebral compression fractures compared to standard medical therapy. Maturitas 2012;72(01):42-49

22 Hulme PA, Krebs J, Ferguson SJ, Berlemann U. Vertebroplasty and kyphoplasty: a systematic review of 69 clinical studies. Spine 2006;31(17):1983-2001

23 Stevenson M, Gomersall T, Lloyd Jones M, et al. Percutaneous vertebroplasty and percutaneous balloon kyphoplasty for the treatment of osteoporotic vertebral fractures: a systematic review and cost-effectiveness analysis. Health Technol Assess 2014; 18(17):1-290
24 Borgström F, Beall DP, Berven S, et al. Health economic aspects of vertebral augmentation procedures. Osteoporos Int 2015;26(04): 1239-1249

25 Bae H, Shen M, Maurer P, et al. Clinical experience using Cortoss for treating vertebral compression fractures with vertebroplasty and kyphoplasty: twenty four-month follow-up. Spine 2010;35 (20):E1030-E1036

26 Wang H, Sribastav SS, Ye F, et al. Comparison of Percutaneous Vertebroplasty and Balloon Kyphoplasty for the Treatment of Single Level Vertebral Compression Fractures: A Meta-analysis of the Literature. Pain Physician 2015;18(03):209-222

27 Hsieh MK, Chen LH, Chen WJ. Current concepts of percutaneous balloon kyphoplasty for the treatment of osteoporotic vertebral compression fractures: evidence-based review. Biomed J 2013;36 (04):154-161

28 Liu JT, Liao WJ, Tan WC, et al. Balloon kyphoplasty versus vertebroplasty for treatment of osteoporotic vertebral compression fracture: a prospective, comparative, and randomized clinical study. Osteoporos Int 2010;21(02):359-364

29 Song D, Meng B, Gan M, et al. The incidence of secondary vertebral fracture of vertebral augmentation techniques versus conservative treatment for painful osteoporotic vertebral fractures: a systematic review and meta-analysis. Acta Radiol 2015;56(08):970-979

30 Chen LX, Li YL, Ning GZ, et al. Comparative efficacy and tolerability of three treatments in old people with osteoporotic vertebral compression fracture: a network meta-analysis and systematic review. PLoS One 2015;10(04):e0123153

31 Elder BD, Lo SF, Holmes C, et al. The biomechanics of pedicle screw augmentation with cement. Spine J 2015;15(06):1432-1445

32 Srinivasan D, Than KD, Wang AC, et al. Radiation safety and spine surgery: systematic review of exposure limits and methods to minimize radiation exposure. World Neurosurg 2014;82(06):1337-1343

33 Ivanishvili Z, Fourney DR. Incorporating the Spine Instability Neoplastic Score into a Treatment Strategy for Spinal Metastasis: LMNOP. Global Spine J 2014;4(02):129-136

34 Wood KB, Li W, Lebl DR, Ploumis A. Management of thoracolumbar spine fractures. Spine J 2014;14(01):145-164

35 Chandra RV, Yoo AJ, Hirsch JA. Vertebral augmentation: update on safety, efficacy, cost effectiveness and increased survival? Pain Physician 2013;16(04):309-320

36 Yang LY, Wang XL, Zhou L, Fu Q. A systematic review and metaanalysis of randomized controlled trials of unilateral versus bilateral kyphoplasty for osteoporotic vertebral compression fractures. Pain Physician 2013;16(04):277-290

37 Khan OA, Brinjikji W, Kallmes DF. Vertebral augmentation in patients with multiple myeloma: a pooled analysis of published case series. AJNR Am J Neuroradiol 2014;35(01):207-210

38 Wang LJ, Yang HL, Shi YX, Jiang WM, Chen L. Pulmonary cement embolism associated with percutaneous vertebroplasty or kyphoplasty: a systematic review. Orthop Surg 2012;4(03):182-189

39 Bliemel C, Oberkircher L, Buecking B, Timmesfeld N, Ruchholtz S, Krueger A. Higher incidence of new vertebral fractures following percutaneous vertebroplasty and kyphoplasty-fact or fiction? Acta Orthop Belg 2012;78(02):220-229

40 Body JJ, Bergmann P, Boonen S, et al. Non-pharmacological management of osteoporosis: a consensus of the Belgian Bone Club. Osteoporos Int 2011;22(11):2769-2788

41 Lutz S, Berk L, Chang E, et al; American Society for Radiation Oncology (ASTRO). Palliative radiotherapy for bone metastases: an ASTRO evidence-based guideline. Int J Radiat Oncol Biol Phys 2011;79(04):965-976

42 Röllinghoff M, Zarghooni K, Dargel J, et al. The present role of vertebroplasty and kyphoplasty in the treatment of fresh vertebral compression fractures. Minerva Chir 2010;65(04):429-437

43 Mendel E, Bourekas E, Gerszten P, Golan JD. Percutaneous techniques in the treatment of spine tumors: what are the diagnostic and therapeutic indications and outcomes? Spine 2009;34(22, Suppl)S93-S100 
44 Krueger A, Bliemel C, Zettl R, Ruchholtz S. Management of pulmonary cement embolism after percutaneous vertebroplasty and kyphoplasty: a systematic review of the literature. Eur Spine J 2009;18(09):1257-1265

45 Felder-Puig R, Piso B, Guba B, Gartlehner G. [Kyphoplasty and vertebroplasty for the management of osteoporotic vertebral compression fractures: a systematic review]. Orthopade 2009; 38(07):606-615

46 McGirt MJ, Parker SL, Wolinsky JP, Witham TF, Bydon A, Gokaslan ZL. Vertebroplasty and kyphoplasty for the treatment of vertebral compression fractures: an evidenced-based review of the literature. Spine J 2009;9(06):501-508

47 Shen MS, Kim YH. Vertebroplasty and kyphoplasty: treatment techniques for managing osteoporotic vertebral compression fractures. Bull NYU Hosp Jt Dis 2006;64(3-4):106-113

48 Witham TF, Khavkin YA, Gallia GL, Wolinsky JP, Gokaslan ZL. Surgery insight: current management of epidural spinal cord compression from metastatic spine disease. Nat Clin Pract Neurol 2006;2(02):87-94, quiz 116

49 DaFonseca K, Baier M, Grafe I, et al. [Balloon kyphoplasty in the treatment of vertebral fractures]. Unfallchirurg 2006;109(05): 391-399, quiz 400

50 Verlaan JJ. Comment on: efficacy and safety of balloon kyphoplasty in the treatment of vertebral compression fractures: a systematic review (C. Bouza et al.). Eur Spine J 2006;15(07):1068-1069

51 Popp AW, Isenegger J, Buergi EM, Buergi U, Lippuner K. Glucocorticosteroid-induced spinal osteoporosis: scientific update on pathophysiology and treatment. Eur Spine J 2006;15(07):1035-1049

52 Lemke DM. Vertebroplasty and kyphoplasty for treatment of painful osteoporotic compression fractures. J Am Acad Nurse Pract 2005;17(07):268-276

53 Laredo JD, Hamze B. Complications of percutaneous vertebroplasty and their prevention. Semin Ultrasound CT MR 2005;26(02):65-80
54 Cotten A, Dewatre F, Cortet B, et al. Percutaneous vertebroplasty for osteolytic metastases and myeloma: effects of the percentage of lesion filling and the leakage of methyl methacrylate at clinical follow-up. Radiology 1996;200(02):525-530

55 Ratliff J, Nguyen T, Heiss J. Root and spinal cord compression from methylmethacrylate vertebroplasty. Spine 2001;26(13):E300-E302

56 Lopes NM, Lopes VK. Paraplegia complicating percutaneous vertebroplasty for osteoporotic vertebral fracture: case report. Arq Neuropsiquiatr 2004;62(3B):879-881

57 Chiras J, Depriester C, Weill A, Sola-Martinez MT, Deramond H. [Percutaneous vertebral surgery. Technics and indications]. J Neuroradiol 1997;24(01):45-59

58 Syed MI, Jan S, Patel NA, Shaikh A, Marsh RA, Stewart RV. Fatal fat embolism after vertebroplasty: identification of the high-risk patient. AJNR Am J Neuroradiol 2006;27(02):343-345

59 Yoo KY, Jeong SW, Yoon W, Lee J. Acute respiratory distress syndrome associated with pulmonary cement embolism following percutaneous vertebroplasty with polymethylmethacrylate. Spine 2004;29(14):E294-E297

60 Jang JS, Lee SH, Jung SK. Pulmonary embolism of polymethylmethacrylate after percutaneous vertebroplasty: a report of three cases. Spine 2002;27(19):E416-E418

61 Kim SY, Seo JB, Do KH, Lee JS, Song KS, Lim TH. Cardiac perforation caused by acrylic cement: a rare complication of percutaneous vertebroplasty. AJR Am J Roentgenol 2005;185(05):1245-1247

62 Edmonds CR, Barbut D, Hager D, Sharrock NE. Intraoperative cerebral arterial embolization during total hip arthroplasty. Anesthesiology 2000;93(02):315-318

63 Xiao H, Yang J, Feng X, et al. Comparing complications of vertebroplasty and kyphoplasty for treating osteoporotic vertebral compression fractures: a meta-analysis of the randomized and non-randomized controlled studies. Eur J Orthop Surg Traumatol 2015;25(Suppl 1):S77-S85 